\title{
Self-Regulation as A Mediator Between the Effect of Mental Accounting on Decision Satisfaction of Car Purchases
}

\author{
Asri Rejeki \\ Student of Doctoral Psychology, Universitas Airlangga, Surabaya, Indonesia \\ Universitas Muhammadiyah Gresik, Gresik, Indonesia \\ rejeki.asri@yahoo.co.id \\ Tatik Suryani \\ STIE Perbanas, Surabaya, Indonesia \\ tatik@perbanas.ac.id \\ Siti Sulasmi \\ Business Economics Faculty, Universitas Airlangga, Surabaya, Indonesia \\ Siti.sulasmi@unair.ac.id
}

\begin{abstract}
This study aims to determine the effect of mental accounting on satisfaction with purchase decision, using self-regulation as a mediator. Previous studies about post-purchase have focused on decision satisfaction - despite the latter being an antecedent of satisfaction. This study attempts to view decision satisfaction through the lense of mental accounting, namely how consumers code and categorize income as well as evaluate spendings. This is a quantitative research that studies consumers who bought cars in Jakarta and Surabaya. The sample consist of 316 participants, recruited through convenient sampling technique. The measuring instrument used is a modified Decision Satisfaction Questionnaire (SWD) by Holmes-Roy, 3item Self-Regulation Questionaire to measure Self-Regulation to buy, and 2-item Mental Budgeting Questionnaire to measure mental accounting. These are all in the form of a 5-item Likert scale. The validity of the item is done using the Rasch model. Data analysis was performed using partial least squares PLS-SEM with the use of Software SmartPLS 3. The findings indicate that self-regulation acts as a mediator between mental accounting and decision satisfaction. Decision Satisfaction as First order is affected directly by the second order, which is "Good Enough", "Not Available", "Move On" and "Happy with the decision". Self-Regulation as a mediator variable positioned as First order is influenced directly by the Second order, namely "Strategy", “Control”, "Objective”, "Evaluation”, "Progress”, and "Firmness". Mental Accounting as First order is influenced directly by Second order, namely "Frame", "Category", and "Evaluation".
\end{abstract}

Keywords : decision satisfaction, mental accounting, self-regulation. 


\section{Introduction}

This study focuses on exploring how consumers make purchases by making optimal choices and attain customer satisfaction. However, research that examines decision satisfaction is scarce. Studies that look into decision satisfaction is important (Heitmann, Lehmann, \& Herrmann, 2007). Westbrook \& Newman 1978; Westbrook, Newman, and Taylor 1978 stated that the experience of being satisfied and dissatisfied is not only attached to the product but also the decision-making process (Westbrook \& Newman, 1978; Westbrook, Newman, \& Taylor, 1978). Payne, Bettman, and Johnson 1993 stated that consumers with product knowledge have some difficulties identifying satisfaction, and are satisfied with their decisions (Payne \& Bettman, 1992). While Fitzsimons, Greenleaf, and Lehmann (1997) concluded that there is a positive relationship between decision satisfaction and satisfaction (Fitzsimons, Greenleaf, \& Lehmann, 1997). According to Zhang and Fitzsimons (1999), decision satisfaction depends on the availability of various options and the alignment of various types of attributes (Zhang \& Fitzsimons, 1999). Based on previous studies it appears that decision satisfaction is important. Consumers who feel dissatisfied when making decisions usually feel a sense of regret for the product they bought. This condition will positively affect customer satisfaction and repurchase (Heitmann et al., 2007).

\section{Cognitive Dissonance Theory for Decision Satisfaction}

Leon Festinger developed the cognitive dissonance theory. Dissonance is a form of a psychological discomfort that elicit stress (Oliver, 20I5). Several conditions that could affect dissonance: (I) threshold effect, (2) a decision which cannot be withdrawn, (3) commitment to, and importance of, the decisions, (4) lack of alternatives, (5) desired alternatives with exclusive mutual features, (6) alternatives that are not qualitatively equal, (7) personal willingness and responsibility. Two situations typically arise in the face of dissonance, namely comparing the feeling of regret (regret comparator) and reducing dissonance. Feeling of remorse appears when a dissonance reduction does not occur. In contrary, expetation will emerge when dissonance reduction occurs.

Car purchases involve a complex decision making. Consumers faces a situation where they must choose the car attributes that are in line with their expectation (consonance) and those 
that are not (dissonance). Consumers use a variety of strategies in decision making, namely (a) optimizing, choosing the best identified option, (b) satisfying, choosing satisfying alternatives, but not the best, (c) maximax, choosing the most profitable alternative, and (d) maximin, choosing the most minimal alternative from the worst alternative (Ahmed \& Omotude, 2012). Satisfaction-oriented consumers will be satisfied by products that meet the minimum threshold - declared "good enough" (Weaver, Daniloski, Schwarz, \& Cottone, 2015). Many factors influence decision satisfaction. Cultural values, emotional values and word of mouth affect decision satisfaction (Jamil, ul Hassan, Farid, \& Ahmad, 2017). Individual determinants, namely anticipation of regret and perceived search cost, affect decision satisfaction (Fassnacht, Schmidt, \& Pannek, 20I5). Prices are relatively high, and the frequency of purchases is rare. This condition will usually affect an individual's financial condition. Therefore, mental accounting is needed.

\section{Mental Accounting}

Mental accounting refers to the cognitive process that explains how individuals manage value, such as money. It answers many questions regarding why individuals classify incomes, and whether the grouping and classification systems are satisfactory (Thaler, 1999). Consumers are more likely to be satisfied by their decision making process when they have mental accounting capabilities. This is because decisions would be made through mature financial considerations.

Mental accounting involve the process of consumers coding and categorizing their incomes as well as evaluating their spendings. This affect the type of items consumers would want to purchase. Consumers will regulate between their mental accounting and the product they wish to buy. Some studies have shown that mental accounting affects self-control (Otto, Davies, \& Chater, 2018).

\section{Self-Regulation}

Self-regulation is the process of managing ones' thought, emotion, impulse, performance, and behavior based on standards. This standard includes goals, norms, values, morals, laws, expectations and similar responses by others or by oneself in the past (Baumeister, 2018). Consumers adjust their purchases based on the previously allocated fund. This allows them 
to avoid any purchases that could ignite short-term satisfaction and yet be detrimental to their future. Products are typically classified into two: products for pleasure (hedonist) or products that are sufficient following their use only (Mowen \& Minor, 200I). Consumers conduct self-regulation to choose products that are suitable for their financial capabilities. Through self-regulation, consumers set a strategy for making purchases, especially high involvement product.

Consumers are more satisfied when decisions are based on their goal or purpose. Choice of compatible or exchangeable goals can reduce dissonance and increase decision satisfaction (Shao \& Shao, 20lI). This shows that consumers who can adjust their desires will produce satisfying decisions. Consumers use self-regulation strategies to implement intentions to make better decisions and reflects it through their action (Gollwitzer \& Sheeran, 2009).

Other studies show that shopping sophistication is the key influence towards consumers' satisfaction with their buying experience. Sophistication not only affects satisfaction but also perception of control, fairness (fair) and dissonance (mismatch). Consumers with a more realistic expectations of product quality, performance, and consequence, will feel less dissatisfied with their buying decisions (Newell, Wu, Titus, \& Petroshius, 20I I).

There is a positive relationship between evaluating the costs incurred with decision satisfaction. Consumers who spend more time and effort to find information about products are typically more satified with their decision. Consumers try to build, evaluate, and realign the schemes on the new product they want to buy. These types of consumers will be more satisfied than those who rely solely on simple processes (Wang \& Shukla, 2013).

\section{Relationship between variables}

According to Thaler (1999) mental accounting is a cognitive process that explains how individuals manage values like money. Mental accounting answers many questions about why individuals classify and classify sources and whether grouping and classification systems can be satisfactory (Thaler, 1999). Through mental accounting skills, consumers are more likely to be satisfied with their decision, because they are made with mature financial considerations (Thaler, 1999). 
The relationship between Mental accounting and self-regulation to buy

Consumers codes and categorizes their income and evaluate spendings. This affects what items consumers would want to consume or buy. Consumers perform self-regulation to buy. Consumers adjust their consumption or purchase goods based on the previously allocated funds. Consumers exercise self-control in spending their money. Through self-regulation, consumers avoid purchases that only provide short-term pleasure (Mowen \& Minor, 200I).

Koch and Nafziger (2013) shows that individuals use mental accounting to see the availability of the resources they have when deciding on a product. Next, they use self-control to sort out which product to buy. Individuals create expectation and set reference points when they create goals. Based on this predetermined reference point, individuals make low psychological points to motivate them in achieving their goal (Koch \& Nafziger, 20I3) - be it choosing a product that brings pleasure (hedonist) or simply because it is useful. Similarly, through mental accounting, consumers determine strategies for making purchases, especially on products that require high involvement. The strategy can be in the form of cash or credit purchases. Mental accounting affects self-control (Otto et al., 20I8). Consumers conduct selfregulation to choose products based on their financial capabilities.

The relationship between self-regulation to buy and decision satisfaction

Consumers will be more satisfied when the choice is based on their goal and purpose. Research conducted by Shao et al. (2010) shows that the choice of compatible or exchangeable goals can reduce dissonance after choice and ultimately can increase decision satisfaction (Shao \& Shao, 20II). This shows that consumers who can adjust or revise their desires will produce satisfying decisions.

Gollwitzer \& Sheeran (2009) shows that consumers uses self-regulation strategies when implementing intentions to make better decisions and turn it into action (Gollwitzer \& Sheeran, 2009). Newell et al. (20II) research found that shopping sophistication is the key, whether consumers are satisfied with the buying experience. Communication not only affects satisfaction but also perceptions of control, fairness and dissonance. Consumers who are more realistic about the expectations of product quality and performance and their 
consequences will feel more satisfied with their buying decisions (Newell, Wu, Titus, \& Petroshius, 201 I).

Wang and Shukla (2013) found that there is a positive relationship between evaluation costs and satisfaction with decision making. Consumers who spend more time and effort to find information about products will feel more satisfied with their choice. Consumers try to build, evaluate and realign the schema on the new product they want to buy. Consumers will be more satisfied than those who rely solely on simple processes (Wang \& Shukla, 2013).

Therefore, the hypotheses are as followed:

$\mathrm{HI}$ : Decision satisfaction is influenced by mental accounting through self-regulation as a mediator.

$H 2$ : Decision satisfaction as the first order is influenced directly by the second order, good enough, not obsessed, move on and happy with the decision.

$H 3$ : Self-regulation as a mediator variable positioned as first order is directly influenced by the second-order, namely strategy factor, control, objective, flexible, evaluation, progress, and firmness.

H4: Mental accounting as first order is influenced directly by second-orders, namely frame, category, and self-evaluation.

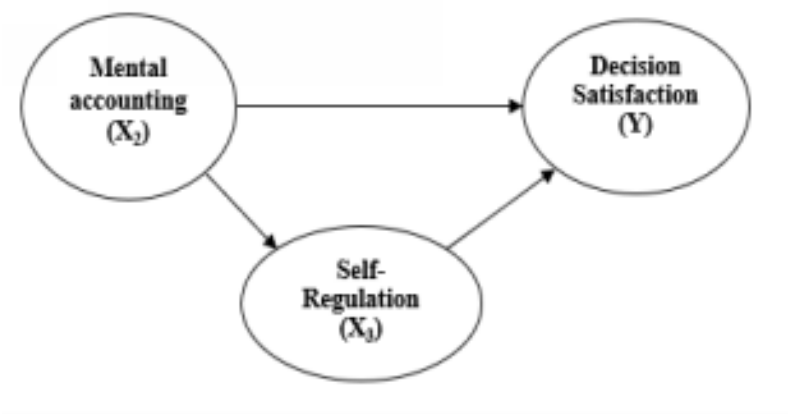

Figure I.Conceptual framework 


\section{Method}

\section{Respondents}

A total of 316 people who bought a car in Jakarta or Surabaya participated in this study. Participants must have purchased the car within a maximum time frame of 6 months from the study. The minimum amount of sample size refers to Cohen, with the basis of the number of arrow directions leading to the dependent variable (Hair, Hult, Ringle, \& Sarstedt, 20I4). The sampling technique used is the convenience sampling technique.

\section{Measurement}

The measurement tool is a modification of the Satisfaction with Decision (SWD) questionnaire from Holmes-Royter which consists of three items: modification of two items of Perry's (200I) Mental Budgeting Scale to measure Mental accounting (Perry, 200I). To measure self-regulation, modification of four items is done towards the Self-Regulation Questionnaire (SRQ) from Brown, Miller, \& Lawensowski (1999) (Brown, Miller, \& Lawendowski, 1999). This is a 5-point Likert scale. The validity of the items was tested using the Rasch model (Linacre, 2012; Sumintono \& Widhiarso, 20I5)

Table I

Sample item

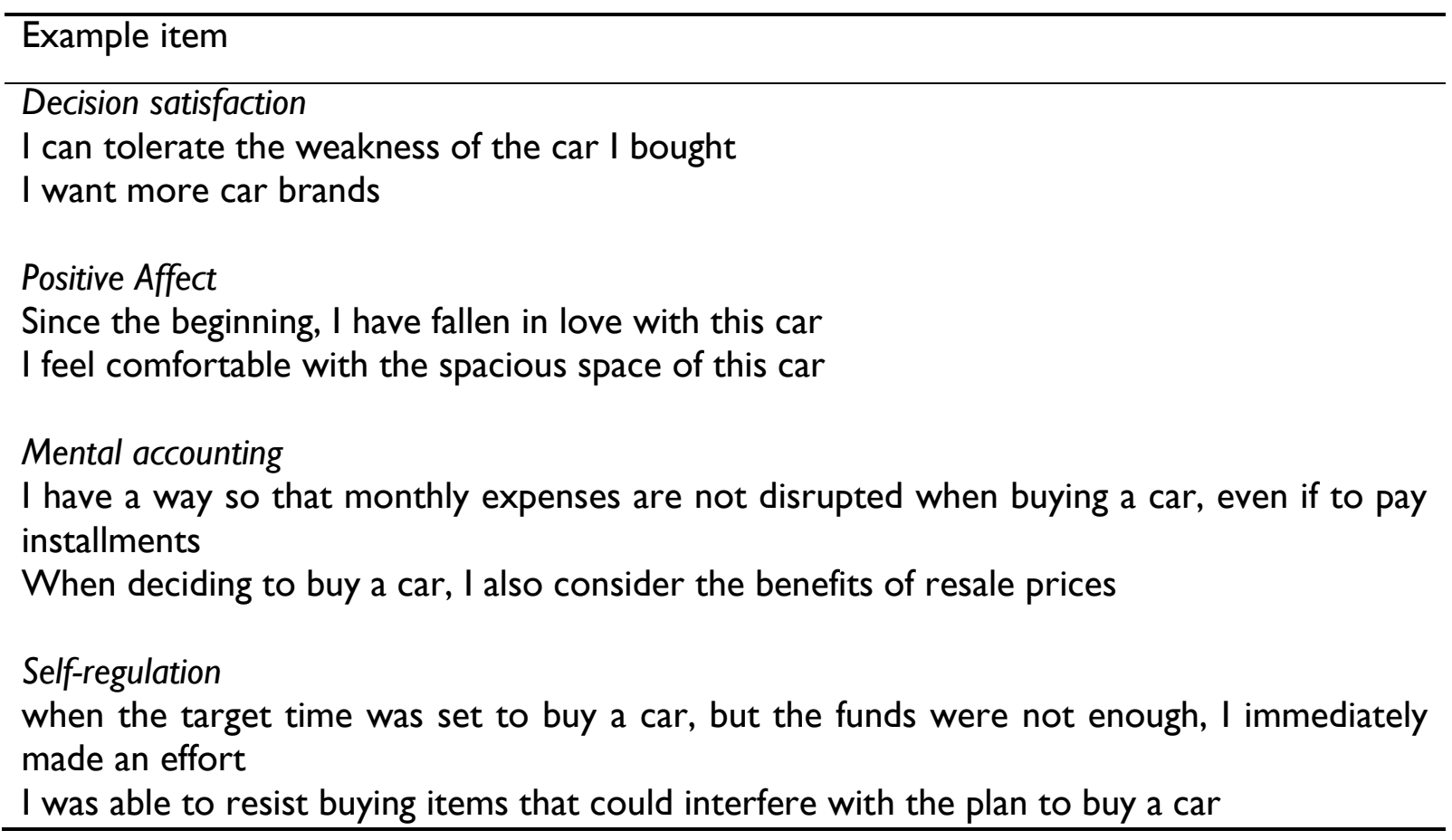


Calculation results of validation and reliability of the Rasch model

Decision Satisfaction Questionnaire

The Decision Satisfaction Questionnaire obtained a Rasch reliability score of 0.97 indicating adequate reliability and a Cronbach alpha reliability of 0.75 . Based on the calculation it appears that item dimensionality (DIM) shows a percentage score of $31.6 \%$, meaning that the items in this gauge do not contain other dimensions. The highest logit lies on item no. 29 (1.06) while the lowest logit lies on item no. $6(-0.79)$.

\section{Mental accounting Questionaire}

Analysis of the Mental Accounting Questionnaire shows that it has an item reliability score of 0.96 indicating good items, as well as good alpha Cronbach reliability. The highest logit is on item no 26 . The lowest logit is on item 45 . DIM measurements of $26.4 \%$ indicate that overall items do not overlap with other dimensions.

\section{Self-regulation Questionaire}

Analysis of the self-regulation questionnaire shows an item reliability score of 0.98 which indicates a good item. The Cronbach alpha reliability score shows 0.66 indicating a good item. The highest logit is on item no. 7I. The highest logit indicates that the item has the highest difficulty level for the respondent to approve the lowest Logit statement on item no. 8. The lowest logit shows the most available item for the respondent to approve the statement. The lowest logit shows the most available item for the respondent to approve the statement. Overall the items do not contain other dimensions, indicated by DIM measurements of $24.4 \%$. Thus, the authors conclude that the Self Regulation items can be used for research.

\section{Data analysis}

PLS-SEM partialleast squares were performed to analyze the data (Ghozali, 20 I I; Hair et al., 20I4). SEM-PLS is a multivariate statistical analysis aimed at obtaining a predictive model of the relationship between exogenous factor pathways towards endogenous factors, with a variance based data approach. The first stage of analysis is to test the validity and reliability of the factors in the outer model. Next, the internal model is also tested, particularly to 
evaluate the path of the influence of the relationship between exogenous to endogenous factors. Once the outer and inner model are tested, the final model of SEM will be obtained, which is the model of the findings. The path analysis is conducted to determine the value of the total effect, direct effect and indirect effect of exogenous factors on endogenous factors.

\section{Result}

Measuring model

The first step is measurement of convergent validity. Convergent validity is assessed through factors loadings of Composite Reliability (CR) and Average Variance Extracted (AVE).

\section{Convergent validity}

Hair, Ringle \& Sarstedt (20I4) state that indicators with a loading factor less than 0.4 must be removed from the model (Hair et al., 2014). Furthermore, indicators with a loading factor between 0.4 to 0.7 are also advised to be eliminated. in the case where it increases CR or AVE, However, if no increase is evident, then the minimum limit of 0.4 is considered a significant indicator in explaining or measuring the factor.

Table I shows the result of convergent validity testing, where the Factor Loadings displayed are Outer Loadings obtained after omitting values below 0.4 on the initial model. This is the second model. In other words, the indicators in the second model has already validly explained and measured the factors. As seen from Table I, items discarded due to factor loadings below 0.4 are XII.9, X13.7, X13.8, X22.2, X23.I, X24.I, X24.2, X27.3, Y13.

\section{Construct reliability}

Construct reliability procedure is done to test whether the factors that make up the research model are reliable. The reliability is assessed via composite reliability and Cronbach alpha. Hair (2014) stated that reliable factors will have a composite reliability and Cronbach alpha score $>0.7$. Meanwhile, it is acceptable if the scores are between 0.6 to 0.7 . In this study, the composite reliability of mental accounting, self-regulation, and decision satisfaction are $0.905,0.78 \mathrm{I}$ and 0.828 respectively. Therefore, all variables are accepted. 
Table I

Convergent validity

\begin{tabular}{|c|c|c|c|c|c|c|}
\hline $\begin{array}{l}\text { Second Order } \\
\text { Factor }\end{array}$ & $\begin{array}{l}\text { First Order } \\
\text { Factor }\end{array}$ & Item & $\begin{array}{l}\text { Loading } \\
\text { factor }\end{array}$ & AVE & CR & $\begin{array}{l}\text { Cronbach's } \\
\text { Alpha }\end{array}$ \\
\hline Mental & Frame & XII_I & 0.612 & $0.76 I$ & 0.905 & 0.842 \\
\hline \multirow[t]{25}{*}{ Accounting } & & $\times 1 I^{-2}$ & 0.700 & & & \\
\hline & & $\times 1 I^{-3}$ & 0.677 & & & \\
\hline & & XII_4 & 0.723 & & & \\
\hline & & XII_5 & 0.578 & & & \\
\hline & & $\times 1 I^{-6} 6$ & 0.438 & & & \\
\hline & & $\times 1 I^{-7} 7$ & 0.572 & & & \\
\hline & & XII_8 & 0.580 & & & \\
\hline & Category & X12_I & 0.626 & & & \\
\hline & & $\times 12 \_2$ & 0.631 & & & \\
\hline & & $\times 12 \_3$ & 0.558 & & & \\
\hline & & $X 12 \_4$ & 0.490 & & & \\
\hline & & X12_5 & 0.404 & & & \\
\hline & & $\times 12$ & 0.645 & & & \\
\hline & & $\times 12 \_7$ & 0.667 & & & \\
\hline & & X12_8 & 0.521 & & & \\
\hline & & X12_9 & 0.554 & & & \\
\hline & & $\times 12 \_10$ & 0.579 & & & \\
\hline & Evaluation & X13_I & 0.667 & & & \\
\hline & & X13_2 & 0.435 & & & \\
\hline & & X13_3 & 0.622 & & & \\
\hline & & $\times 13 \_4$ & $0.55 \mathrm{I}$ & & & \\
\hline & & $\times 13 \_5$ & 0.684 & & & \\
\hline & & $\times 13$ & 0.660 & & & \\
\hline & Strategy & X2I_I & $0.6 \mathrm{II}$ & 0.382 & 0.781 & 0.672 \\
\hline & & X2I_2 & 0.521 & & & \\
\hline \multirow[t]{13}{*}{ Self-Regulation } & & X2I_3 & 0.652 & & & \\
\hline & & X2I_4 & 0.694 & & & \\
\hline & & X2I_5 & 0.737 & & & \\
\hline & Control & X22_I & 0.525 & & & \\
\hline & & $\times 22 \_3$ & $0.54 I$ & & & \\
\hline & & $X 22 \_4$ & 0.668 & & & \\
\hline & & X22_5 & 0.529 & & & \\
\hline & & $X 22 \_6$ & 0.639 & & & \\
\hline & & X23_3 & 0.830 & & & \\
\hline & & $\times 23 \_4$ & 0.675 & & & \\
\hline & & X23_5 & 0.545 & & & \\
\hline & Flexible & & & & & \\
\hline & Evaluation & X25_I & I & & & \\
\hline
\end{tabular}




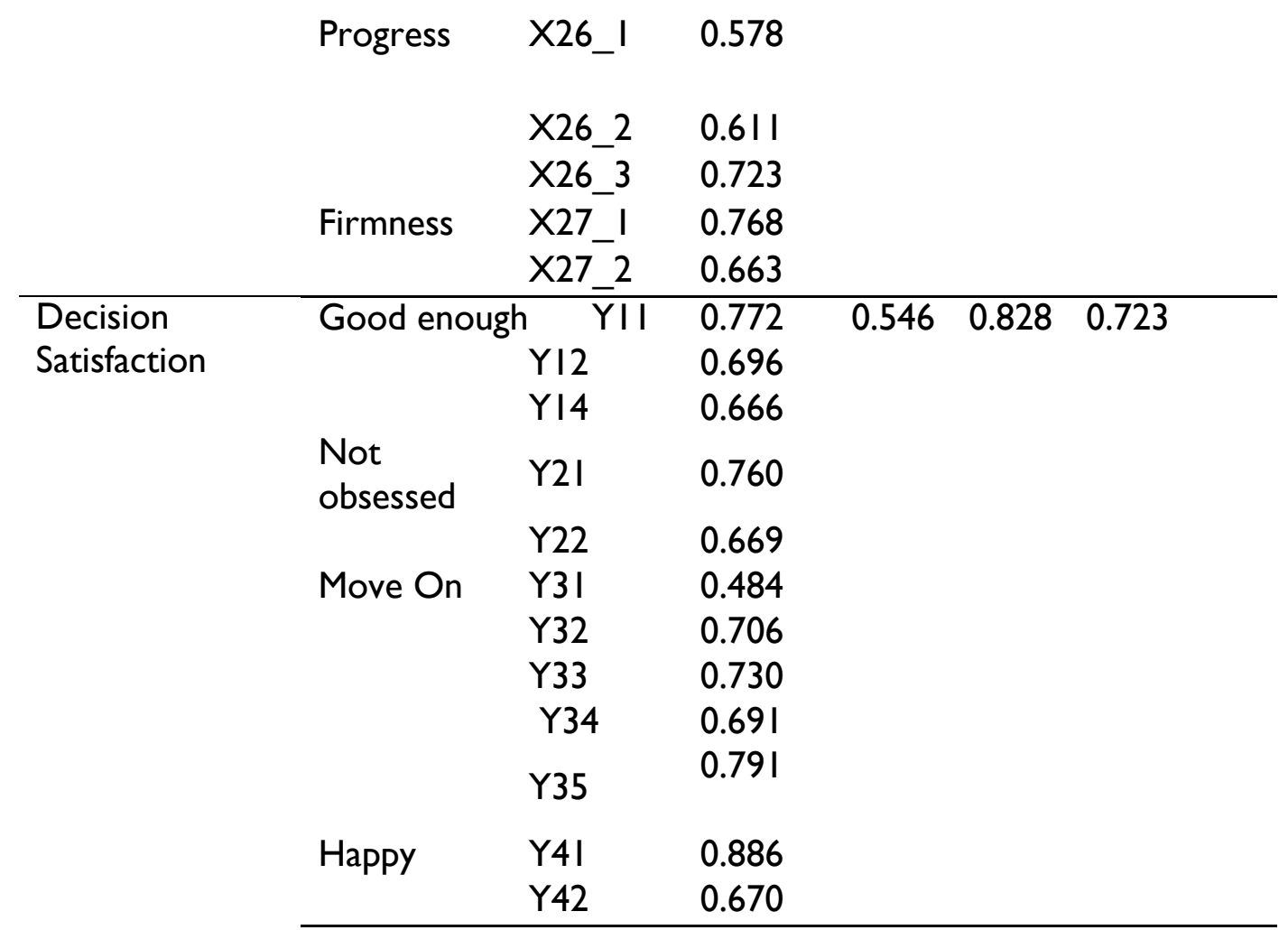

Source: Results of primary data processing (2018)

\section{Discriminant validity}

The discriminant validity test aims to ensure that the Outer Loading values has stronger relationship with its own indicators relative to other factors in the model. Discriminant validity is assessed using Cross Loading and Fornell-Larcker Criterion. Cross Loading indicates how strong each item from an indicator is against items in other factors. Hair (2014) states that indicators are considered valid when the value of the loading factor is larger than the crossloading.

Meanwhile, to establish discriminant validity via Fornell-Larcker Criterion, the AVE value should be compared with corresponding correlation values with other variables. Hair (2014) states a group of indicators would be considered valid in explaining a factor if the root value of AVE is larger than the correlation score between factors. The findings show that the crossloading value of all indicators has a greater loading factor compared to its' cross loading. This is indicated in bold in Table I. The Fornell-Larcker Criterion value (root value of AVE) for mental accounting (0.872), self-regulation (0.654) and decision satisfaction (0.739), is of higher value than the most significant correlation value to other factors. Thus, it can be concluded that 
indicators in the second model are valid in explaining its own factors compared to other factors.

Table 2

Value of Cross Loading and Fornell-Larcker Criterion second model

\begin{tabular}{llll}
\hline Cross Loadings & Mental Accounting & Self Regulation & Decision Satisfaction \\
\hline$(X 11)$ Frame & $\mathbf{0 . 8 9 4}$ & 0.525 & 0.409 \\
$(X 12)$ Category & $\mathbf{0 . 9 0 2}$ & 0.642 & 0.415 \\
$(X 13)$ Evaluation & $\mathbf{0 . 8 1 9}$ & 0.540 & 0.256 \\
$(X 21)$ Strategy & 0.546 & $\mathbf{0 . 6 9 8}$ & 0.564 \\
$(X 22)$ Control & 0.576 & $\mathbf{0 . 7 6 I}$ & 0.483 \\
$(X 23)$ Purpose & 0.253 & $\mathbf{0 . 6 1 5}$ & 0.429 \\
$(X 25)$ Self Evaluation & 0.329 & $\mathbf{0 . 5 1 3}$ & 0.190 \\
$(X 26)$ Progress & 0.510 & $\mathbf{0 . 7 8 8}$ & 0.349 \\
$(X 27)$ Firmness & 0.318 & $\mathbf{0 . 5 8 2}$ & 0.250 \\
$(Y 1)$ GoodEnough & 0.361 & 0.501 & $\mathbf{0 . 7 2 5}$ \\
(Y2) Not obsessed & 0.287 & 0.403 & $\mathbf{0 . 7 6 2}$ \\
(Y3) MoveOn & 0.381 & 0.447 & $\mathbf{0 . 7 2 8}$ \\
(Y4) Happy Decision & 0.207 & 0.367 & $\mathbf{0 . 7 4 1}$ \\
\hline Fornell-Larcker Criterion & & & Decision Satisfaction \\
\hline & Mental Accounting & Self Regulation & $\mathbf{0 . 7 3 9}$ \\
Decision Satisfaction & 0.416 & 0.580 & 0.416 \\
Mental Accounting & $\mathbf{0 . 8 7 2}$ & 0.654 & 0.580 \\
Self Regulation & 0.618 & $\mathbf{0 . 6 5 4}$ &
\end{tabular}

Source: Results of primary data processing (2018)

Structural model

Testing of inner model based on the value and significance of path coefficients, the coefficient of determination $\left(R^{2}\right)$, effect size $\left(f^{2}\right.$ and $\left.q^{2}\right)$ as well as predicted relevance $\left(Q^{2}\right)$.

Path Coefficient test

The path coefficient test is conducted by applying t-statistics to examine the effect of path coefficients that connect an exogenous factor on an endogenous factor. When t-statistic results are greater than the pre-defined significance threshold, it is concluded that the path coefficient for the exogenous-endogenous path is significantly different than zero, resulting in real effect of exogenous factor to its endogenous counterpart. The calculation for 
significance threshold using error tolerance $(\alpha)=5 \%$ and total sample $(n)=316$, with $t_{(d f=n-1 \text {; }}$ $\alpha / 2)$ formula is $t_{(315 ; 0.025)}=1.96$.

Table 3

Comparison of test results influences path coefficients on the initial and second inner models

\begin{tabular}{|c|c|c|c|c|c|c|}
\hline \multirow{2}{*}{$\begin{array}{l}\text { A relationship between } \\
\text { exogenous factors towards } \\
\text { endogenous factors }\end{array}$} & \multicolumn{3}{|c|}{ Early Model } & \multicolumn{3}{|c|}{ Second Model } \\
\hline & $\begin{array}{l}\text { Value of } \\
\text { Influence }\end{array}$ & $\begin{array}{l}\mathrm{T} \\
\text { statistics }\end{array}$ & Information & $\begin{array}{l}\text { Value of } \\
\text { Influence }\end{array}$ & $\begin{array}{l}\mathrm{T} \\
\text { statistics }\end{array}$ & Information \\
\hline $\begin{array}{l}\text { Mental Accounting -> } \\
\text { Decision Satisfaction }\end{array}$ & 0.061 & 0874 & $\begin{array}{l}\text { Not } \\
\text { significant }\end{array}$ & \multicolumn{3}{|c|}{$\begin{array}{l}\text { Relationships are omitted because they } \\
\text { are not significant }\end{array}$} \\
\hline $\begin{array}{l}\text { Mental Accounting } \rightarrow \text { Self } \\
\text { Regulation }\end{array}$ & 0.653 & 16,497 & Significant & 0.654 & 15,900 & Significant \\
\hline $\begin{array}{l}\text { Self Regulation } \rightarrow \text { Decision } \\
\text { Satisfaction }\end{array}$ & 0.547 & 8,024 & Significant & 0.580 & 12,394 & Significant \\
\hline $\begin{array}{l}\text { Mental Accounting } \rightarrow \\
\text { XI I.Frame }\end{array}$ & 0.873 & 63,436 & Significant & 0.868 & 61,704 & Significant \\
\hline $\begin{array}{l}\text { Mental Accounting } \rightarrow \\
\text { XI2. Category }\end{array}$ & 0.894 & 91,549 & Significant & 0.894 & 93,977 & Significant \\
\hline $\begin{array}{l}\text { Mental Accounting } \rightarrow \\
\text { XI3.Evaluation }\end{array}$ & 0.826 & 30,453 & Significant & 0.812 & 29,180 & Significant \\
\hline $\begin{array}{l}\text { Self Regulation } \rightarrow \\
\text { X21.Strategy }\end{array}$ & 0.737 & 26,209 & Significant & 0.732 & 26,526 & Significant \\
\hline $\begin{array}{l}\text { Self Regulation -> } \\
\text { X22.Control }\end{array}$ & 0.744 & 24,263 & Significant & 0.744 & 23,866 & Significant \\
\hline Self Regulation $\rightarrow$ X23.Goal & 0.580 & 13,910 & Significant & 0.557 & 15.108 & Significant \\
\hline $\begin{array}{l}\text { Self Regulation } \rightarrow \\
\text { X24.Flexible }\end{array}$ & 0.188 & 1,413 & $\begin{array}{l}\text { Not } \\
\text { significant }\end{array}$ & \multicolumn{3}{|c|}{$\begin{array}{l}\text { Relationships are omitted because they } \\
\text { are not significant }\end{array}$} \\
\hline $\begin{array}{l}\text { Self Regulation } \rightarrow \text { X25.Self } \\
\text { evaluation }\end{array}$ & 0.497 & 7,591 & Significant & 0.514 & 8.415 & Significant \\
\hline $\begin{array}{l}\text { Self Regulation } \rightarrow \times 26 \text {. } \\
\text { Progress }\end{array}$ & 0.620 & 12,453 & Significant & 0.625 & 16,240 & Significant \\
\hline $\begin{array}{l}\text { Self Regulation } \rightarrow \\
\text { X27.Firmness }\end{array}$ & 0.612 & 13,873 & Significant & 0.594 & 13,085 & Significant \\
\hline $\begin{array}{l}\text { Decision Satisfaction } \rightarrow \\
\text { YI.Good enough }\end{array}$ & 0.779 & 29,087 & Significant & 0.758 & 27,437 & Significant \\
\hline $\begin{array}{l}\text { Decision Satisfaction } \rightarrow \\
\text { Y2.Not obsessed }\end{array}$ & 0.758 & 21,317 & Significant & 0.759 & 22,831 & Significant \\
\hline $\begin{array}{l}\text { Decision Satisfaction } \rightarrow \\
\text { Y3.Move On }\end{array}$ & 0.736 & 25,694 & Significant & 0.737 & 23,727 & Significant \\
\hline $\begin{array}{l}\text { Decision Satisfaction } \rightarrow \\
\text { Y4.Happy Decision }\end{array}$ & 0.744 & 20,614 & Significant & 0.747 & 22,285 & Significant \\
\hline
\end{tabular}

Based on the comparison table, the results of the early models of the second model, it is known that the early models are two insignificant relationships namely between mental accounting with decision satisfaction and factors flexible with self-regulation. This is indicated by the value of t-statistics which is less than the significance threshold $(I, 96)$. Hence in the 
second model, the two paths with insignificant relationships are then eliminated. The second model contains only significant relationship paths (t-statistics the value is higher than $1.96 \mathrm{t}$ table value). This model was later determined as the final model of the SEM-PLS.

\section{Coefficient of determination}

The coefficient of determination $\left(R^{2}\right)$ assesses the extent of variation (data diversity) in the endogenous factor that can be explained by exogenous factors in inner models. Hair (20l4), states that $R^{2}<0.25$ is considered weak, $R^{2}$ between $0.25-0.5$ is enough, and $R^{2}$ between $0.5-0.75$ is good, and $R^{2}>0.75$ is considered very good. The coefficient determination for Decision satisfaction is $R^{2}=0.336$ and for self-regulation $R^{2}=0.428$, hence both are considered enough.

\section{Predicted relevance $\left(Q^{2}\right)$}

The value of $\mathrm{Q}^{2}$ represents the predictive relevance of endogenous factors in the inner model. Hair (2014) states that if the value of $\mathrm{Q}^{2}$ is greater than zero, then the endogenous factor has the predictive relevance. This research shows that self-regulation and decision satisfaction are higher than zero, hence it is concluded that the model has predictive relevance.

\section{Table 4}

Composite reliability, Cronbach's alpha, AVE, $R^{2}, Q^{2}$

\begin{tabular}{lllllll}
\hline & $\begin{array}{l}\text { Composite } \\
\text { Reliability }\end{array}$ & $\begin{array}{l}\text { Cronbach's } \\
\text { Alpha }\end{array}$ & AVE & $\mathrm{R}^{2}$ & $\mathrm{Q}^{2}$ & $\begin{array}{l}\text { Root } \\
\text { from } \\
\text { AVE }\end{array}$ \\
\hline Mental Accounting & 0.905 & 0.842 & 0.761 & & 0.872 \\
Self Regulation & $0.78 \mathrm{I}$ & 0.672 & 0.382 & 0.428 & 0.149 & 0.654 \\
Decision Satisfaction & 0.828 & 0.723 & 0.546 & 0.336 & 0.171 & 0.739 \\
\hline
\end{tabular}

\section{Effect size $\left(f^{2}\right)$}

The value of $f^{2}$ or effect size is the value that represents how much the portion of exogenous variable variance that contributes to the variation in exogenous factors' determinant coefficient. Hair (20l4), states that, if the value of $f^{2}$ is worth 0.02 , then it is 
considered is a small contribution. If the value of $f^{2}$ is $0.15-0.35$ it is considered sufficient contribution. If the value of $\mathrm{f}^{2}$ is $>0.35$ is called large contribution. The effect size of mental

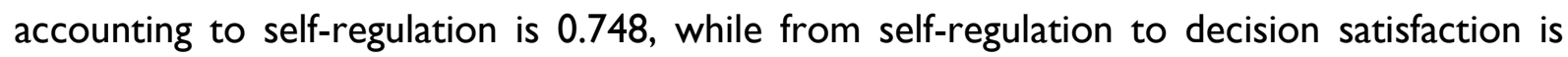
0.507 .

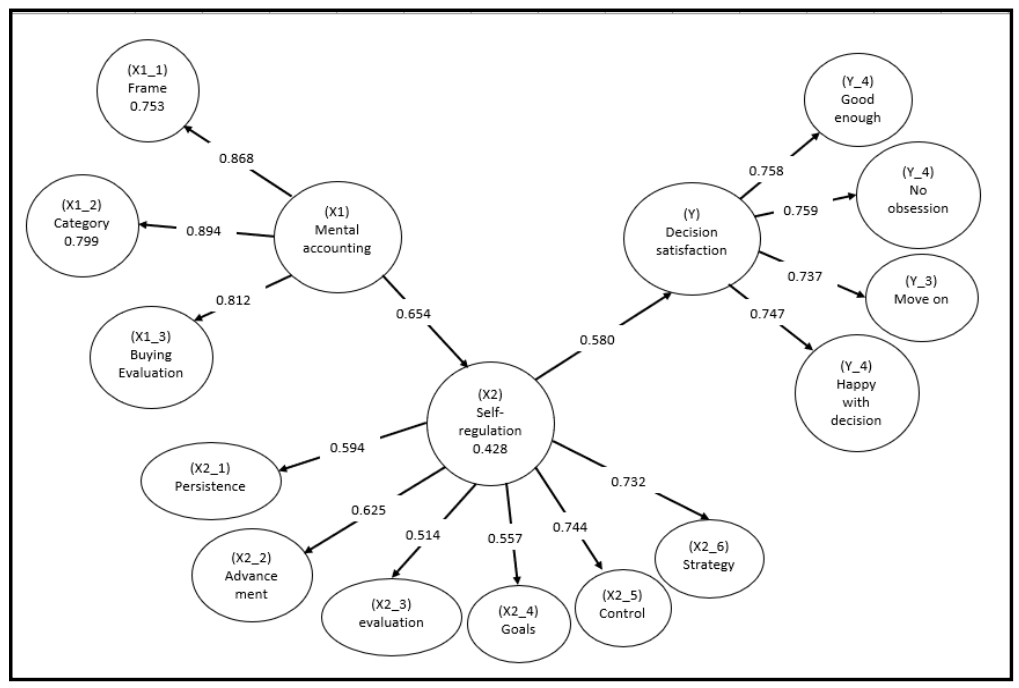

Figure 2 .Model Result

\section{Discussion}

The finding study shows that mental accounting affects decision satisfaction through selfregulation buying as a mediator. The tests show that the working hypothesis is accepted. In other words, mental accounting have a significant indirect influence on decision satisfaction, with self-regulation as a mediator.

This is in line with previous studies that noted how consumers' self-regulation is influenced by how they envision their financial situation could be in the future. Consumers are not easily tempted to buy products that are not needed. They buy products according to a priority scale, future benefits, and capabilities (Kotler \& Armstrong, 20I6). Through selfregulation, consumers avoid purchases that provide short-term pleasure when it could be potentially harmful in the future (Mowen \& Minor, 200I). In such condition, consumers will typically feel more satisfied with their decisions. 
Empirical results show that the number of respondents who limit their spendings is relatively high. This indicates that most respondents have a long-term financial plan (74.4\%). Similarly, there is also a massive number of respondents who categorize their funds. As an implication, most respondents were able to set aside reserve funds (74.1\%). The majority of respondents also evaluate the products they have made. In other words, respondents divide their incomes based on their needs (79.2\%). These results indicate that most of the respondents have a high level of mental accounting.

The findings also indicate that the total effect of the mental accounting-self-regulationdecision satisfaction pathway is higher than the direct influence of mental accounting on decision satisfaction. This shows that mental accounting affects decision satisfaction when respondents perform self-regulation. The willingness of respondents to be discipline with funds, namely to hold and regulate themselves to purchase based on mental accounting, plays an essential role. It shows that the planning of the use of household funds, such as framing, categorizing and evaluating, will influence decision satisfaction when respondents can hold and regulate their buying impulses.

Mental accounting has a significant direct effect on Self Regulation. The results of this study strengthen the research conducted by Koch and Nafziger (2016) who state that mental accounting is how people "arrange a basketball." Through mental accounting, people control their expenditures, both for pleasure or necessity (e.g., clothing, food) (Koch \& Nafziger, 2016).

Besides, this study is the underscore opinion of Mowen and Minor (200I) who states that consumers adjust their consumption based on their previously allocated funds. Consumers control themselves in spending their money; in other words, consumers conduct selfregulation. Research conducted by Townsend (2012) highlights that planning does not always help self-control or self-regulation. Planning with concrete forms is easier to control than abstract planning. Purchasing planning that involves emotional control is more difficult than cognitive control (Townsend \& Liu, 20I2). 
The results show that the dominant indicators of mental accounting are category, frame, and evaluation. Respondents categorize income, frame income, and evaluate their expenditures, affecting how they regulate themselves when pusrchasing a product. High involvement product purchases affects respondents' self-control over what they would purchase. It is a matter of what is desired versus what can be bought. For example, respondent $A$ wants to buy a Honda CR-V, however $A$ ended up buying a Honda Brio Satya due to price considerations. In this example, the purchase outside the purchasing power limit will affect the commercial design that has been set for mental accounting.

The finding show that mental accounting affects self-regulation. The buying and selling strategies for determining the steps, type, brand and target time of purchase, and how the monitors monitor the progress of the target purchase. This study indicates that Selfregulation has a direct effect on decision satisfaction. The results of this study confirm the study conducted by Vohs et al. (2008) that self-regulation influences decision making (Vohs \& Baumeister, 2016). Likewise, it strengthens the research findings of Shao et al. (2010) who states that consumers who regulate themselves can adjust the conditions for buying products, subsequently increasing their satisfaction in decision making (Shao \& Shao, 20I I).

The results of this study is in line with Newell et al. (20II) who discovered that consumers who are more realistic about product quality and product performance will be more satisfied by their purchases. It also confirms Gollwitzer and Sheeran (2009) study that depict how consumers who carry out self-regulation strategy in buying will be satisfied by their decision making (Gollwitzer \& Sheeran, 2009).

The empirical results show that the dominant indicators of self-control are self-regulation, strategy, and purchase progress. Respondents with strong self-control tend to get satisfaction in decision making. Respondents were able to control their desires according to their abilities. The findings show the strategies that consumers in the high category use for buying high involvement product products. Most of the respondents devised a strategy to buy cars (88.6\%) and adjusted their desire for financial conditions (86.3\%). Consumers see progress in the stages needed when the buying process is in a high category - most of the gradual respondents with progress from the adequacy of their funds $(82.6 \%)$. The results of 
the company show the firmness of consumers to particular products following the initial objectives. Most people tried to get the car they wanted (7I.2\%).

Dirinea and Lordanescu (2013) shows that there is a significant difference in account structure in decision making. Additionally, there is no significant difference in the level of decisions consumption based on sex (Dirinea \& lordănescu, 20I3). The above conditions affect respondents to accept, moves in from what he wants to buy versus what he can afford, feel what he has decided "good enough". From the above, it appears that Selfregulation influences decision satisfaction.

This research also shows that being "good enough", "not obsessed", "move on", and "happy" are indicators of decision satisfaction. Strategy, control, precision, flexibility, evaluation, progress, and constancy are indicators of self-regulation. Meanwhile, frame, category, and evaluation are indicators of mental accounting.

\section{Limitation}

The limitation of this study is that it has not explored the differences in credit and cash purchases. Cultural factors may have an effect on the individual's perspective on financial planning going forward, for example to investment.

\section{Conclusion}

In purchasing cars - a high involvement product - a complete financial design is needed. The main commercial design is that consumers must be able to allocate funds that are associated with their needs. Next, consumers must be able to categorize the needs and financial posts to meet these financial needs. This mental attitude of the consumer is referred to as mental accounting. Mental accounting will affect decision satisfaction if mediated by self-regulation. The results of this study show that frames of indicators, categories and evolution influence mental accounting. Self-regulation is influenced by indicators of fitness, progress, evaluation, control objectives, strategy. While decision satisfaction is influenced by indicators of good enough, not obsessed, move on and happy with the decision. 
Data in the field shows that mental accounting influences decision satisfaction through selfregulation. Therefore it is recommended that producers develop marketing methods that can change the mindset of consumers, ensuring that other benefits can still cover poor car attributes. For example, bundling car sales by giving discounts on car insurance, routine services, car accessory cash back, or car loans with relatively affordable installments and interest.

Data in the field shows that self-regulation influences decision satisfaction, meaning that salesperson not only sell products but also acts as an advisor. They help consumers find products that are suitable for their purpose by evaluating and determining the purchasing strategy.

Consumers should have sufficient financial knowledge so they can plan household expenditure properly. Such installments should not interfere with family finances. Similarly, car maintenance costs must be calculated so it could run comfortably without disrupting family finances.

Mental accounting is not particularly popular in Indonesia, particularly when it comes to future financial planning (e.g., saving stocks, investing, designing family finances) to evaluate items that have been purchased. To increase awareness, such skill should be introduced from an early age.

\section{Acknowledgment}

The authors appreciate the scholarship from BPPDN, as well as the financial aid for the research project from Directorate General of Research and Development at the Ministry of Research, Technology and Higher Education, Indonesia.

\section{References}

Ahmed, M. T., \& Omotude, H. (20I2). Theories and strategies of good decision making. International Journal of Scientific \& Technology Research, I(I0), 5I-54.

Baumeister, R. F. (2018). Self-regulation and self-control. New York: Routledge. 
Brown, J., Miller, W., \& Lawendowski, L. (1999). The Self-regulation questionnaire (SRQ). Retrieved from https://casaa.unm.edu/inst/SelfRegulation Questionnaire (SRQ).pdf

Dirinea, M., \& lordănescu, E. (2013). Mental account barriers and transaction purpose: A romanian point of view. Procedia - Social and Behavioral Sciences, 78(0), 44I-445. https://doi.org/http://dx.doi.org/I0.1016/j.sbspro.2013.04.327

Fassnacht, M., Schmidt, T., \& Pannek, J. (20I5). Determinants of choice satisfaction in a highinvolvement product choice. Journal of Management and Marketing Research, 18, I-19.

Fitzsimons, G. J., Greenleaf, E. A., \& Lehmann, D. R. (1997). Decision and consumption satisfaction: Implication for channel relations. Columbia.

Ghozali, I. (20I I). Structural equation modeling: Metode alternatif dengan partial least square PLS. Semarang: Badan Penerbit Universitas Diponegoro.

Gollwitzer, P. M., \& Sheeran, P. (2009). Self-regulation of consumer decision making and behavior: The role of implementation intentions. Journal of Consumer Psychology, 19(4), 593-607. https://doi.org//0.1016/j.jcps.2009.08.004

Hair, J. F. J., Hult, G. T. M., Ringle, C., \& Sarstedt, M. (2014). A primer on partial least squares structural equation modeling (PLS-SEM). Long range planning. https://doi.org// 0.1016/j.Irp.2013.01.002

Heitmann, M., Lehmann, D. R., \& Herrmann, A. (2007). Choice goal attainment and decision and consumption satisfaction. Journal of Marketing, XLIV(May), 234-250.

Jamil, R. A., ul Hassan, S. R., Farid, A., \& Ahmad, N. (2017). Investigating the impact of consumer values and advocacy behavior on buying decision satisfac-tion: A study through gender lens. Management Science Letters, 7, 185-196. https://doi.org/I0.5267/j.msl.20I7.I.00I

Koch, A. K., \& Nafziger, J. (2013). Goals and mental accounting. Journal of Economic Theory, 162, I-68. https://doi.org/10.1016/j.jet.2016.01.00I

Kotler, P., \& Armstrong, G. (2016). Principles of marketing (I6th ed.). Boston: Pearson.

Linacre, J. M. (2012). A user's guide to winsteps ministep: Rasch-model computer programs. Program Manual 3.75.0. Australia: Winsteps.com.

Mowen, J. C., \& Minor, M. (200I). Consumer behavior (5th ed.). New York: Hartcourt College Publisher.

Newell, S. J., Wu, B. T., Titus, P. A., \& Petroshius, S. M. (20II). The role of shopping sophistication in creating satisfying purchase outcomes. American Journal of Business, 26(2), I29-I44. https://doi.org/I0.1 I08/I9355 I8I I I I I745 I6

Oliver, R. L. (20I5). Satisfaction: A behavioral perspective on the consumer (2nd ed.). New York: Routledge. 
Otto, P. E., Davies, G. B., \& Chater, N. (2018). Note on ways of saving: Mental mechanisms as tools for self-control? (Vol. 44). London.

Payne, J. W., \& Bettman, J. R. (1992). Behavioral decision research : A constrctive processing perspective. annual reviews psychology, 43, 87-131. Retrieved from https://www0.gsb.columbia.edu/mygsb/faculty/research/pubfiles/ I 34/annual_review_co nstructive.pdf

Perry, V. G. (200I). Antecedents of consumer financing decesions: A mental accounting model of revilving credit usage. Advances in Consumer Research, 28, I3-25.

Shao, W., \& Shao, G. (20II). Understanding choice-goal compatibility, dissonance and decision satisfaction. Australasian Marketing Journal (AMJ), 19(I), |4-21. https://doi.org/I0.1016/j.ausmj.2010.11.003

Sumintono, B., \& Widhiarso, W. (20I5). Aplikasi model Rasch: Untuk penelitian ilmu-ilmu sosial. Cimahi: Trim Komunikata Publishing House.

Thaler, R. H. (1999). Mental accounting matters. Journal of Behavioral Decision Making, I2(3), 183-206.

Vohs, K. D., \& Baumeister, R. F. (Eds.). (2016). Handbook of self-regulation: Research, theory, and applications (3rd ed). New York: The Guilford Press.

Wang, Q., \& Shukla, P. (2013). Linking sources of consumer confusion to decision satisfaction: The role of choice goals. Psychology \& Marketing, 30(4), 295-304. https://doi.org// 0.1002/mar.20606

Weaver, K., Daniloski, K., Schwarz, N., \& Cottone, K. (20I5). The role of social comparison for maximizer and satisficers: Wanting the best or wanting to be the best? Journal of Consumer Psychology, I-17. Retrieved from http://dx.doi.org/10.1016/j.jcps.2014.10.003

Westbrook, R. A., \& Newman, J. W. (1978). An analysis of shopper dissatisfaction for major household appliances. Journal of Marketing Research, I5(3), 456-466.

Westbrook, R. A., Newman, J. W., \& Taylor, J. R. (1978). Satisfaction/dissatisfaction in the purchase decision process. Journal of Marketing, 42(4), 54-60. https://doi.org// 0.I I 77/002224297804200408

Zhang, S., \& Fitzsimons, G. J. (1999). Choice-process satisfaction: The influence of attribute alignability and option limitation. Organizational Behavior and Human Decision Processes, $77(3),|92-2| 4$. 